\title{
PELATIHAN PENGGUNAAN APLIKASI SISTEM PAKAR DIAGNOSA PENYAKIT KULIT PADA MASYARAKAT DI KECAMATAN TOMBATU KABUPATEN MINAHASA TENGGARA
}

\author{
Cindy P. C. Munaiseche \\ Fakultas Teknik, Universitas Negeri Manado \\ cindymunaiseche@gmail.com
}

\begin{abstract}
Abstrak
Salah satu masalah di dalam dunia medis atau kedokteran adalah adanya ketidakseimbangan antara pasien dan dokter. Keterbatasan yang dimiliki seorang ahli/expert (dalam hal ini dokter) terkadang menjadi kendala bagi masyarakat yang akan melakukan konsultasi untuk mendapatkan solusi pengobatan terbaik terkait dengan penyakit yang diderita. Selain itu, sebagian besar dari masyarakat tidak terlatih secara medis sehingga apabila mengalami gejala penyakit yang diderita belum tentu dapat memahami cara-cara penanggulangannya. Sangat disayangkan apabila gejala-gejala yang sebenarnya dapat ditangani lebih awal menjadi penyakit yang lebih serius akibat kurangnya pengetahuan. Dalam hal ini sistem pakar dihadirkan sebagai alternatif kedua dalam memecahkan permasalahan setelah seorang ahli (expert). Aplikasi sistem pakar yang disosialisasikan penggunaannya kepada masyarakat dan tenaga medis di Kecamatan Tombatu Kabupaten Mitra adalah sistem pakar untuk mendiagnosa jenis penyakit kulit pada manusia. Pelatihan ini bertujuan untuk membantu masyarakat dalam mendeteksi penyakit kulit sejak dini atau pada saat seseorang mulai merasakan gejala-gejala lain yang tidak seperti biasanya atau merasakan gangguan pada kulitnya maka dapat segera menggunakan aplikasi sistem pakar ini untuk mendeteksi kemungkinan timbulnya jenis penyakit kulit tertentu berdasarkan gejala yang dialaminya beserta solusi pengobatannya, tanpa harus ke dokter terlebih dahulu untuk berkonsultasi sehingga tindakan penanganan atau pencegahan dapat dilakukan sejak awal. Kegiatan pelatihan ini dilaksanakan dalam empat tahapan, yaitu: persiapan, pelaksanaan, evaluasi dan pelaporan hasil kegiatan. Pelatihan ini dapat meningkatkan keterampilan masyarakat dan tenaga medis dalam menggunakan teknologi komputer yang dilengkapi aplikasi sistem pakar untuk mendiagnosa penyakit kulit.
\end{abstract}

Kata Kunci: sistem pakar, expert system, diagnosa, penyakit kulit, Tombatu, Mitra.

\section{PENDAHULUAN}

Sistem pakar merupakan program komputer yang mampu menyimpan pengetahuan dan kaidah seorang pakar/ahli yang khusus. Keterbatasan yang dimiliki seorang expert (dokter) terkadang menjadi kendala bagi masyarakat yang akan melakukan konsultasi untuk mendapatkan solusi pengobatan terbaik terkait dengan penyakit yang diderita. Pengetahuan sebenarnya dapat diperoleh dari buku-buku atau situs-situs internet yang membahas tentang kesehatan. Akan tetapi, untuk mempelajari hal tersebut tidaklah mudah karena selain memerlukan waktu yang cukup lama untuk memahaminya, sumbersumber tersebut juga belum tentu dapat mendiagnosis jenis penyakit seperti yang dilakukan oleh seorang dokter, apalagi bagi masyarakat yang tinggal di perkampungan yang belum memiliki dokter ahli. Oleh karena itu, di dunia kedokteran, sudah banyak bermunculan aplikasi sistem pakar. Sistem pakar ini mampu mendiagnosis 
berbagai jenis penyakit pada manusia, baik penyakit kulit, THT (telinga, hidung, tenggorokan), mulut, organ dalam (jantung, hati, ginjal), maupun AIDS (Hamdani, 2010).

Aplikasi sistem pakar yang akan disosialisasikan penggunaannya kepada masyarakat adalah sistem pakar untuk mendiagnosa jenis penyakit kulit pada manusia. Organ kulit dipilih karena kulit merupakan indera peraba dan organ terluas penyusun tubuh manusia yang terletak paling luar serta menutupi seluruh permukaan tubuh. Karena letaknya paling luar, maka kulit yang pertama kali menerima rangsangan seperti rangsangan sentuhan, rasa sakit, maupun pengaruh buruk dari luar. Dalam interaksi antar manusia, kulit merupakan organ yang pertama kali digunakan untuk bersalaman, bersentuhan, berciuman, dan sebagainya sedangkan beberapa penyakit dapat tertular hanya dengan melalui sentuhan, atau interaksi kulit dengan kulit, atau penggunaan media bekas (handuk, baju, jaket, sapu tangan, dan sebagainya) yang digunakan oleh orang yang mempunyai penyakit kulit menular. Mungkin banyak orang menganggap penyakit kulit adalah hal yang sepele. Namun, sebenarnya penyakitpenyakit pada kulit ini bisa sangat berbahaya jika didiamkan terus menerus. Bahkan beberapa penyakit pada kulit juga mampu mengakibatkan kematian.

Perangkat lunak sistem pakar yang ada dapat mengenali jenis penyakit kulit setelah melakukan konsultasi dengan menjawab beberapa pertanyaan yang ditampilkan oleh aplikasi sistem pakar serta dapat menyimpulkan beberapa jenis penyakit kulit yang di derita oleh pasien. Disamping itu, aplikasi yang ada dapat memberikan solusi atau tindakan yang dapat dilakukan oleh pasien sehubungan dengan penyakit kulit yang dideritanya.

Kabupaten Minahasa Tenggara terdiri dari 6 Kecamatan, yaitu: Belang, Pusomaen, Ratatotok, Touluaan, Tombatu, dan Ratahan. Kabupaten Minahasa Tenggara memiliki Rumah Sakit Umum Daerah (RSUD) Noongan. Rumah sakit milik pemerintah ini terletak di ruas jalan Ratahan - Langowan, dengan alamat Jalan Raya Noongan, Langowan Barat. Adapun rumah sakit ini menyediakan fasilitas Pelayanan Spesialisasi Klinik (Kulit, Anak, Bedah, Penyakit Dalam, Kebidanan dan Kandungan, Kulit dan Kelamin, Poli Gigi), Rehabilitasi Medik, IGD (Instalasi Gawat Darurat), dan Pelayanan Rawat Inap. Kecamatan Tombatu sendiri memiliki dua Puskesmas dengan kategori Rawat Inap, yaitu: Puskesmas Tombatu yang terletak di desa Tombatu II dan Puskesmas Molompar yang terletak di desa Molompar. Dokter yang ada di puskesmas hanyalah dokter umum dan belum ada dokter spesialis kulit yang ditempatkan. Untuk berkonsultasi dengan dokter spesialis kulit, masyarakat harus pergi ke Rumah Sakit Noongan yang ada di kecamatan Ratahan yang jaraknya cukup jauh. 
Dari data statistik kesehatan, Minahasa Tenggara (Mitra) memiliki sejumlah fasilitas kesehatan, yaitu : satu rumah sakit, 11 puskesmas, 46 dokter, 55 bidan, sedangkan jumlah tenaga medis posyandu sebanyak 144 orang. Ternyata, fasilitas kesehatan dan tenaga medis di Minahasa Tenggara masih minim, saat ini Mitra hanya memiliki satu rumah sakit dengan perbandingan jumlah dokter dan jumlah penduduk adalah 1 : 3.174 orang.

Berdasarkan analisa situasi di atas maka perlu diselenggarakan suatu pelatihan penggunaan aplikasi sistem pakar untuk mendiagnosa penyakit kulit pada masyarakat di Kecamatan Tombatu Kabupaten Minahasa Tenggara (Mitra). Pelatihan yang diterapkan ini diharapkan akan membantu masyarakat dalam mendeteksi penyakit kulit sejak dini atau pada saat seseorang mulai merasakan gejala-gejala lain yang tidak seperti biasanya atau merasakan gangguan pada kulitnya maka dapat segera menggunakan aplikasi sistem pakar ini untuk mendeteksi kemungkinan timbulnya jenis penyakit kulit tertentu berdasarkan gejala yang dialaminya beserta solusi pengobatannya, tanpa harus ke dokter terlebih dahulu untuk berkonsultasi. Disamping itu membantu masyarakat yang ingin mengetahui informasi tentang penyakit kulit tanpa harus membeli dan mencari buku-buku tentang penyakit kulit sehingga tindakan penanganan atau pencegahan dapat dilakukan sejak awal.
Target yang ingin dicapai dalam kegiatan ini, yaitu:

1. Pemahaman tentang sistem pakar di lingkungan masyarakat dan para medis.

2. Peningkatan penguasaaan teknologi komputer khususnya aplikasi sistem yang berbasis komputer bagi masyarakat dan para medis.

3. Kemudahan dalam mendiagnosa jenis penyakit kulit sejak dini berdasarkan gejala-gejala yang dialami beserta solusi yang ditawarkan tanpa harus berkonsultasi dengan dokter spesialis kulit terlebih dahulu.

4. Peningkatan pengetahuan masyarakat tentang jenis-jenis penyakit kulit beserta gejalanya, tindakan pencegahan dan pengobatannya.

Luaran dari kegiatan pelatihan penggunaan aplikasi sistem pakar diagnosa penyakit kulit pada masyarakat di kecamatan Tombatu kabupaten Minahasa Tenggara adalah kemampuan peserta dalam mengoperasikan sistem pakar, melakukan registrasi pada menu konsultasi untuk mendiagnosa penyakit berdasarkan gejala yang diinputkan, melakukan login sebagai admin dan menginput data tentang penyakit dan gejalanya.

\section{METODE PELAKSANAAN \\ Metode Kegiatan}

Untuk melaksanakan kegiatan ini, maka dilaksanakan secara bermitra antara tim pelaksana yaitu dari dosen Program Studi Pendidikan Teknologi Informasi dan 
Komunikasi (PTIK) Fakultas Teknik UNIMA

dengan Pimpinan Kecamatan Tombatu Kabupaten Minahasa Tenggara.

\section{Prosedur Pelaksanaan Kegiatan}

Kegiatan pelatihan ini dilaksanakan dalam empat tahapan yaitu persiapan, pelaksanaan/tindakan, evaluasi hasil kegiatan, dan yang terakhir pelaporan hasil kegiatan.

\section{Tahap Persiapan}

Kegiatan yang dilakukan pada tahapan ini adalah tim pelaksana berkomunikasi dengan Pimpinan Kecamatan yang akan menjadi mitra untuk membicarakan maksud dan tujuan, serta mekanisme pelaksanaan kegiatan ini, kemudian mempersiapkan segala kelengkapan yang dibutuhkan dalam kegiatan nanti, seperti software aplikasi dan software pendukung lainnya yang akan digunakan dalam pelatihan, serta pembuatan petunjuk penggunaan aplikasi (tutorial) untuk memudahkan peserta dalam pemahaman materi.

\section{Tahap Pelaksanaan Pelatihan}

Pelaksanaan pelatihan ini mencakup beberapa hal berikut:

\section{a. Penyajian Materi}

Trainer memberikan materi sesuai dengan konsep pelatihan terkait dengan pengenalan Sistem Pakar dan perangkat lunak aplikasi Sistem Pakar untuk mendiagnosa penyakit kulit pada manusia. Tabel 1 menunjukkan daftar materi yang akan disampaikan/ dipresentasikan.

Kegiatan tanya jawab dilakukan bersamaan dengan penyajian materi. Para peserta dapat langsung berdiskusi dengan para pemateri secara langsung untuk memahamkan materi dan sharing pengalaman terkait dengan masalah yang tengah dibahas dalam materi bersangkutan.

Tabel 1 Daftar Jenis Kegiatan dan Materi

\begin{tabular}{|l|l|}
\hline Jenis Kegiatan & \multicolumn{1}{c|}{ Pokok Bahasan (Materi) } \\
\hline Teori & Pengenalan Sistem Pakar \\
\hline & Pengenalan perangkat lunak aplikasi sistem pakar \\
\hline Praktik & $\begin{array}{l}\text { Penggunaan aplikasi sistem pakar untuk mendiagnosa } \\
\text { penyakit kulit pada manusia }\end{array}$ \\
\hline
\end{tabular}

\section{b. Penugasan Praktik}

Pada akhir materi peserta diberi tugas praktik sesuai materi yang telah disajikan untuk menggali penyerapan dan pemahaman materi. Dalam pelatihan ini para 
peserta ditugaskan untuk menginput gejala penyakit lewat pertanyaan-pertanyaan yang diberikan oleh sistem pakar dan akhirnya akan diperoleh suatu kesimpulan tentang jenis penyakit kulit. Trainer akan mendampingi, memandu dan mengarahkan serta memberikan solusi apabila timbul permasalahan selama penugasan praktik.

\section{Tahap Evaluasi}

Evaluasi ini dilakukan setelah penyampaian materi dan praktik. Indikator keberhasilannya yaitu tiaptiap peserta pelatihan mampu mengoperasikan aplikasi sistem pakar yang ada, lebih khusus dapat menginput gejala-gejala penyakit lewat pertanyaanpertanyaan yang diberikan oleh sistem yang harus dijawab oleh pengguna/peserta pelatihan.

\section{Pelaporan Hasil Kegiatan}

Di akhir kegiatan ini dibuat pelaporan sebagai bukti pertanggungjawaban terhadap instansi yang menugaskan, bahwa kegiatan telah dilaksanakan.

\section{HASIL KEGIATAN}

Kegiatan ini terlaksana, diawali dengan adanya penyusunan beberapa alternatif yang dapat dilakukan dalam memecahkan permasalahan yang dihadapi, yaitu:
1. Pemerintah melakukan pengadaan perangkat komputer di lingkungan kesehatan (rumah sakit, puskesmas dan posyandu) yang dilengkapi dengan suatu aplikasi kesehatan berbasis desktop untuk penyakit kulit.

2. Pemerintah menyediakan tenaga ahli yang menguasai penggunaan teknologi komputer di lingkungan kesehatan sebagaimana yang dibutuhkan.

3. Dinas Kesehatan menambah tenaga pakar, dalam hal ini dokter spesialis kulit yang ditempatkan di rumah sakit atau di puskesmas.

4. Kepada masyarakat dan tenaga medis diberikan kursus dan pelatihan singkat mengenai bagaimana mengoperasikan komputer yang dilengkapi dengan aplikasi sistem pakar untuk mendiagnosa penyakit kulit pada manusia.

Pada dasarnya semua alternatif yang telah dijelaskan dapat ditempuh, tetapi bila dipertimbangkan lebih jauh dari berbagai segi, seperti kesiapan dari tenaga ahli komputer, dokter spesialis kulit, dana yang dapat disediakan, motivasi dari tenaga medis dan masyarakat itu sendiri dan lainlain, maka alternatif yang keempat dirasa lebih tepat untuk dipilih dan dilaksanakan, terutama dalam jangka pendek karena yang dikehendaki adalah penguasaan penggunaan aplikasi sistem pakar yang segera diwujudkan.

Bila alternatif pertama yang dipilih, persoalannya adalah apakah masyarakat 
dan tenaga medis dapat menggunakan aplikasi itu, misalnya untuk melihat gambar-gambar penyakit kulit atau untuk mengetahui bagaimana pencegahan dan pengobatan penyakit kulit tersebut? Dapatkah mereka belajar sendiri untuk menggunakan aplikasi tersebut?

Jika alternatif kedua dan ketiga yang dipilih, persoalannya adalah apakah pemerintah dan dinas kesehatan dapat segera menyediakan tenaga ahli komputer dan menambah dokter spesialis kulit yang diperlukan? Berdasarkan pertimbanganpertimbangan tersebut, maka alternatif keempat dipandang lebih tepat untuk dipilih, dengan beberapa alasan sebagai berikut :

1. Masyarakat dan para medis tidak harus meninggalkan aktivitasnya dalam waktu yang cukup lama.

2. Untuk kebutuhan pelatihan, masyarakat dan para medis tidak perlu mengeluarkan biaya pelatihan, malah mendapatkan bantuan seperlunya untuk bahan-bahan yang diperlukan seperti modul, CD pembelajaran, dan lain-lain.

3. Adanya lembaga pendidikan yang sanggup melaksanakan kegiatan ini (Program Studi PTIK Fakultas Teknik UNIMA) yang memiliki tenaga profesional dalam bidangnya.

4. Aplikasi yang dibuat dapat digunakan oleh banyak orang, dan tanpa biaya yang besar (tidak harus membeli tapi secara gratis diinstal).
5. Masyarakat dapat langsung mendeteksi penyakit kulit sejak dini atau kemungkinan timbulnya jenis penyakit kulit tertentu berdasarkan gejala yang dialaminya beserta solusi pengobatannya, tanpa harus ke dokter terlebih dahulu untuk berkonsultasi.

6. Aplikasi sistem pakar ini dapat membantu aktivitas para dokter spesialis kulit sebagai asisten yang sangat berpengalaman.

Jadi pemecahan masalahnya adalah dengan melaksanakan pelatihan dan kursus singkat secara langsung di lokasi atau wilayah yang menjadi sasaran kegiatan ini. Kegiatan ini dilakukan oleh suatu tim yang memiliki kompetensi profesional dalam bidang tersebut melalui program penerapan IPTEKS yang setiap tahun dilakukan oleh Lembaga Pengabdian pada Masyarakat (LPM) Universitas Negeri Manado.

Cara ini dimaksudkan untuk mengubah kondisi yang ada sekarang ini kepada kondisi yang diharapkan, yaitu kurangnya pengetahuan masyarakat tentang penyakit kulit yang ditimbulkan dari gejala yang dialaminya serta keterbatasan dan ketidakseimbangan antara jumlah dokter kulit dan pasien dalam melakukan konsultasi. Kondisi ini akan dibawa kepada kondisi yang diharapkan, yaitu adanya perluasan pengetahuan masyarakat tentang berbagai jenis penyakit kulit, pencegahan dan solusi pengobatannya serta pendeteksian penyakit kulit sejak dini 
sehubungan dengan gejala-gejala yang dialami oleh masyarakat.
Secara umum, kerangka pemecahan masalah ini dapat digambarkan pada Tabel 2.

Tabel 2 Kerangka Pemecahan Masalah

\begin{tabular}{|c|c|c|}
\hline KONDISI YANG ADA & PELATIHAN SINGKAT & $\begin{array}{l}\text { KONDISI YANG } \\
\text { DIHARAPKAN }\end{array}$ \\
\hline $\begin{array}{l}\text { - Kurangnya } \\
\text { pengetahuan } \\
\text { masyarakat tentang } \\
\text { penyakit kulit yang } \\
\text { ditimbulkan dari } \\
\text { gejala yang dialaminya } \\
\\
\text { - Sebagian besar dari } \\
\text { masyarakat tidak } \\
\text { terlatih secara medis } \\
\text { sehingga apabila } \\
\text { mengalami gejala } \\
\text { penyakit kulit yang } \\
\text { diderita belum tentu } \\
\text { dapat memahami } \\
\text { cara-cara } \\
\text { penanggulangannya } \\
\text { - Keterbatasan dan } \\
\text { ketidakseimbangan } \\
\text { antara jumlah dokter } \\
\text { spesialis kulit dan } \\
\text { pasien dalam } \\
\text { melakukan konsultasi }\end{array}$ & $\begin{array}{l}\text { Faktor-faktor penunjang: } \\
\text { - } \quad \text { Adanya dosen Unima yang } \\
\text { profesional yang siap melaksanakan } \\
\text { pelatihan } \\
\text { - } \quad \text { Tingginya antusias masyarakat untuk } \\
\text { mengikuti pelatihan singkat ini } \\
\text { - } \text { Tersedianyan bantuan dana melalui } \\
\text { program penerapan IPTEKS pada } \\
\text { Lembaga Pengabdian Masyarakat } \\
\text { Unima } \\
\text { - } \quad \text { Adanya sambutan yang baik dari } \\
\text { pihak pemerintah dan lingkungan } \\
\text { medis setempat } \\
\text { Faktor-faktor penghambat: } \\
\text { - Keterbatasan waktu, baik pada pihak } \\
\text { pelaksana (Dosen Unima), maupun } \\
\text { pihak peserta (masyarakat dan para } \\
\text { medis) } \\
\text { - Belum maksimalnya fasilitas yang } \\
\text { menunjang pelaksanaan kegiatan } \\
\text { pelatihan ini } \\
\text { - Sulit mendapat fasilitas dalam jumlah } \\
\text { yang cukup banyak secara gratis } \\
\text { untuk digunakan dalam pelatihan ini }\end{array}$ & $\begin{array}{l}\text { - Adanya perluasan } \\
\text { pengetahuan } \\
\text { masyarakat tentang } \\
\text { berbagai jenis } \\
\text { penyakit kulit yang } \\
\text { umum pada } \\
\text { manusia } \\
\text { - Masyarakat dapat } \\
\text { melakukan tindak } \\
\text { pencegahan atau } \\
\text { pengobatan } \\
\text { penyakit kulit } \\
\\
\text { - Pendeteksian } \\
\text { penyakit kulit sejak } \\
\text { dini sehubungan } \\
\text { dengan gejala-gejala } \\
\text { yang dialami oleh } \\
\text { masyarakat tanpa } \\
\text { harus ke dokter } \\
\text { terlebih dahulu } \\
\text { untuk konsultasi }\end{array}$ \\
\hline
\end{tabular}

Dengan memanfaatkan faktor-faktor penunjang yang ada, serta mengendalikan faktor-faktor penghambat seperti digambarkan diatas, maka diharapkan kegiatan pelatihan ini dapat memberikan hasil yang optimal.

$$
\text { Sasaran yang dituju adalah }
$$
masyarakat umum dari berbagai profesi yang ada di Kecamatan Tombatu Kabupaten Minahasa Tenggara, khususnya yang berprofesi sebagai tenaga medis sangat disarankan untuk mengikuti pelatihan ini karena aplikasi yang diajarkan berhubungan dengan kesehatan. Peserta pelatihan idealnya dibatasi maksimal 25 (dua puluh) orang, dengan pertimbangan luas tempat dan untuk memaksimalkan interaksi antara pemateri dengan peserta.

Pelatihan ini diadakan untuk mensosialisasikan jenis-jenis penyakit kulit yang pada umumnya menyerang manusia beserta gejala dan solusinya melalui penggunaan perangkat lunak aplikasi sistem pakar untuk mendeteksi jenis penyakit kulit yang diderita berdasarkan gejala-gejala yang dialami, oleh karena itu 
peserta yang diharapkan selain masyarakat umum adalah para tenaga medis di lingkungan kesehatan yang memiliki kualifikasi memahami cara penggunaan komputer, setidaknya bisa mengoperasikan komputer PC atau laptop dan memiliki keinginan untuk mengajarkan penggunaan aplikasi sistem pakar ini kepada orang lain yang membutuhkan.

Dengan adanya pelatihan penggunaan aplikasi sistem pakar ini, diharapkan masyarakat dapat menggunakan aplikasi sistem pakar yang ada untuk mendeteksi sejak dini jenis penyakit kulit yang mungkin timbul dari gejala-gejala yang dialami oleh pasien dan bagaimana penanganannya. Kegiatan pengabdian pada masyarakat ini dilaksanakan berdasarkan:

1. Perjanjian Pelaksanaan Pengabdian pada Masyarakat Tahun Anggaran 2016 pada LPM UNIMA.

2. Persetujuan lisan dari pimpinan Kecamatan Tombatu (Camat) Kabupaten Mitra perihal pelaksanaan pelatihan ini.
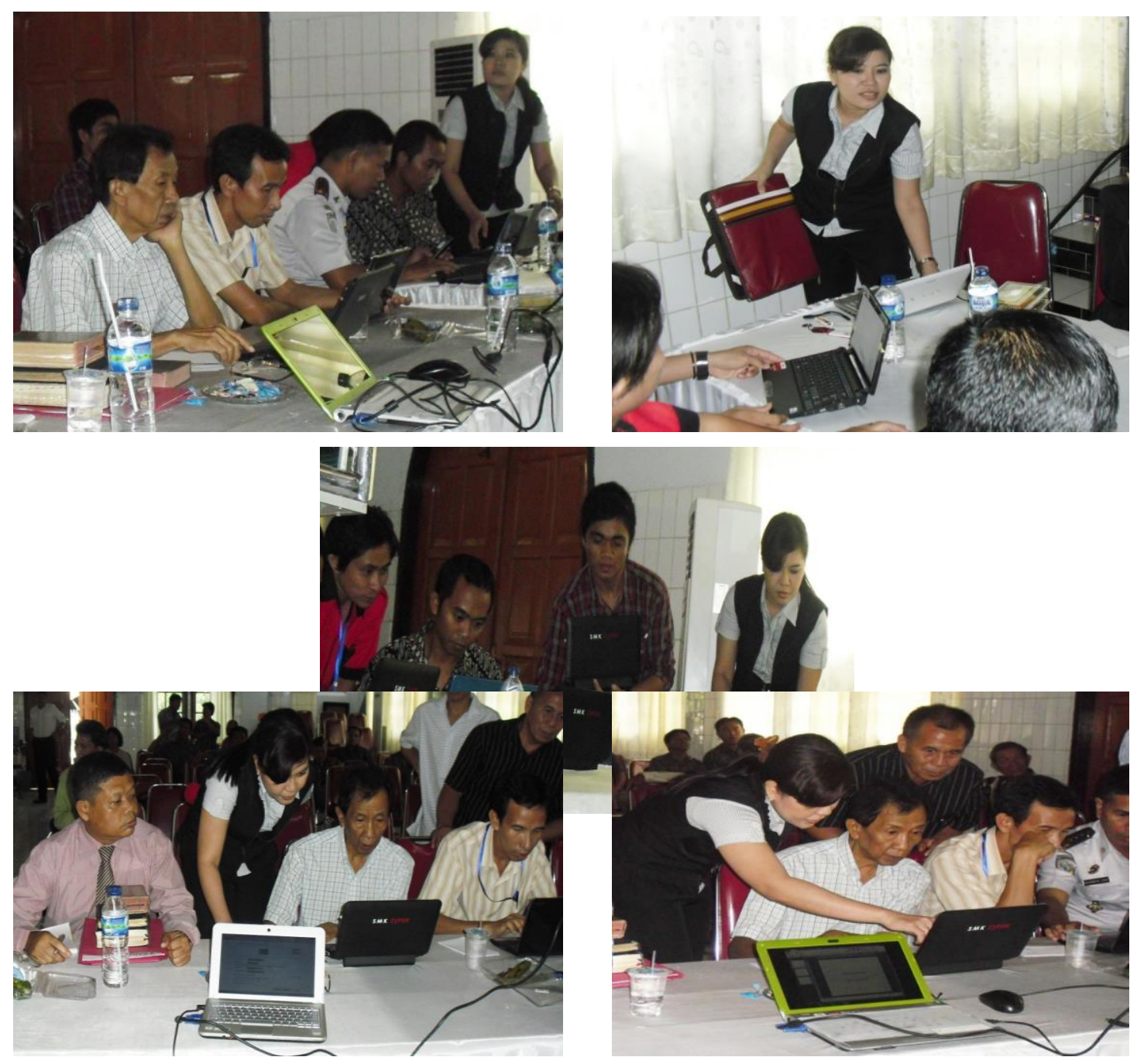

Gambar 1 Foto-Foto Kegiatan Pelatihan 
Berlandaskan dasar pelaksanaan tersebut, kegiatan program pengabdian pada masyarakat ini telah dilaksanakan mulai dari tahap persiapan, tahap pelaksanaan, tahap evaluasi, sampai tahap pelaporan. Untuk menilai sejauh mana keberhasilan pelaksanaan kegiatan ini, telah dilakukan evaluasi terhadap peserta. Hasil yang diperoleh, yaitu: tiap-tiap peserta pelatihan mampu mengoperasikan aplikasi sistem pakar yang ada, lebih khusus dapat menginput gejala-gejala penyakit kulit lewat pertanyaan-pertanyaan yang diberikan oleh sistem yang harus dijawab oleh pengguna/peserta pelatihan.

Dengan adanya kegiatan pelatihan ini, ada beberapa manfaat yang diperoleh, yaitu:

1. Manfaat bagi peserta pelatihan (masyarakat)

- Dapat menambah pengetahuan tentang jenis-jenis penyakit kulit dengan gejala-gejala yang menyertainya.

- Dapat mengetahui jenis penyakit kulit berdasarkan gejala yang dialami secara cepat dan mudah.

- Menjadi penuntun untuk melakukan tindakan yang harus diambil jika mengetahui seberapa besar kemungkinan menderita penyakit kulit.

2. Manfaat bagi instansi kesehatan (medis)

- Membantu proses sosialisasi jenis penyakit kulit pada manusia beserta gejala-gejalanya dan solusi dalam mengatasinya kepada masyarakat .

- Memudahkan para dokter dalam menganalisa penyakit sebelum melakukan pemeriksaan lebih lanjut terhadap pasien.

- Memberikan sumbangan kepada tenaga medis berupa bahan referensi untuk menentukan kemungkinan penyakit kulit yang diderita pasien.

3. Manfaat bagi para ahli sistem pakar

- Dapat mengembangkan sistem pakar diagnosa penyakit kulit yang lebih kompleks.

\section{KESIMPULAN DAN SARAN}

\section{Kesimpulan}

1) Kegiatan pengabdian masyarakat ini berbentuk pelatihan singkat penggunaan aplikasi sisstem pakar untuk mendiagnosa penyakit kulit bagi masyarakat dan para medis telah berhasil dilaksanakan dengan baik dan mencapai tujuan yang diharapkan.

2) Kegiatan ini dapat membantu memperluas pengetahuan masyarakat tentang jenis penyakit kulit, gejala, dan solusinya.

3) Kegiatan ini dapat meningkatkan keterampilan masyarakat dan tenaga medis dalam menggunakan teknologi komputer yang dilengkapi aplikasi sistem pakar untuk mendiagnosa penyakit kulit sejak dini. 
4) Kegiatan ini sebagai usaha pemerataan IPTEKS di daerah Sulawasi Utara, dimana teknologi bukan hanya diperutukkan oleh masyarakat kota besar tetapi juga untuk masyarakat pedesaan.

5) Kegiatan ini merupakan bagian dari upaya peningkatan kualitas penggunaan teknologi komputer yang dilengkapi dengan aplikasi sistem pakar berbasis desktop.

6) Kegiatan ini telah memberikan kontribusi bagi LPM UNIMA untuk mempertimbangkan dalam menetapkan program-programnya diwaktu yang akan datang.

\section{Saran}

1) Kegiatan pengabdian kepada masyarakat seperti ini perlu dilanjutkan dengan materi dan kegiatan yang sama tapi dapat dilaksanakan ditempat yang berbeda, ataupun materi yang berbeda ditempat yang sama, misalnya: pelatihan sistem pakar untuk mendiagnosa penyakit mata.

2) Hubungan kerja sama antara UNIMA dengan pemerintah mulai dari pemerintah provinsi sampai pemerintah desa/kelurahan melalui Lembaga Pengabdian Masyarakat yang selama ini telah terjalin perlu ditingkatkan dan diperluas dalam menangani permasalahan yang berhubungan dengan penggunaan teknologi komputer.

3) Setiap tenaga akademik di Perguruan Tinggi (Dosen) khusunya UNIMA hendaknya peka terhadap kondisi masyarakat serta persoalan yang ada didalamnya, dengan cara memberikan solusi-solusi yang bermanfaat dan berdampak positif.

\section{KEPUSTAKAAN}

Desiani, A., Arhami, M. 2006. Konsep Kecerdasan Buatan. Edisi Pertama, Andi, Yogyakarta.

Hamdani. 2010. Sistem Pakar Untuk Diagnosa Penyakit Kulit Pada Manusia. Jurnal Informatika Mulawarman, Volume 5, Nomor 2.

Handayani, L., Sutikno, T. 2008. Sistem Pakar untuk Diagnosis Penyakit THT Berbasis Web dengan "e2gLite Expert System Shell". Jurnal Teknologi Industri, Volume 12, Nomor 1.

Kumar, S., Prava, D. 2010. An Expert System for Diagnosis of Human Diseases. International Journal of Computer Applications, Volume 1, Nomor 13.

Turban, E., Jay, E.A. 2001. Decision Support System and Intelligent System. Sixth Edition, Prentice Hall International, Inc., New Jersey.Burch, Johm, G. Dkk. (1989). Information System Theory and Practice. Edition : John Wiley \& Sins, Inc. 